University of Montana

ScholarWorks at University of Montana

Integrative Physiology and Athletic Training

Faculty Publications

Integrative Physiology and Athletic Training

$2-2013$

\title{
Blood Oxidative-Stress Markers During a High-Altitude Trek
}

Lindsey E. Miller

Graham R. McGinnis

Brian Kliszczewicz

Dustin Slivka

Walter Hailes

See next page for additional authors

Follow this and additional works at: https://scholarworks.umt.edu/hhp_pubs

Part of the Medicine and Health Sciences Commons

Let us know how access to this document benefits you.

\section{Recommended Citation}

Miller, Lindsey E.; McGinnis, Graham R.; Kliszczewicz, Brian; Slivka, Dustin; Hailes, Walter; Cuddy, John; Dumke, Charles; Ruby, Brent; and Quindry, John C., "Blood Oxidative-Stress Markers During a High-Altitude Trek" (2013). Integrative Physiology and Athletic Training Faculty Publications. 2.

https://scholarworks.umt.edu/hhp_pubs/2

This Article is brought to you for free and open access by the Integrative Physiology and Athletic Training at ScholarWorks at University of Montana. It has been accepted for inclusion in Integrative Physiology and Athletic Training Faculty Publications by an authorized administrator of ScholarWorks at University of Montana. For more information, please contact scholarworks@mso.umt.edu. 
Authors

Lindsey E. Miller, Graham R. McGinnis, Brian Kliszczewicz, Dustin Slivka, Walter Hailes, John Cuddy, Charles Dumke, Brent Ruby, and John C. Quindry 


\title{
Blood Oxidative-Stress Markers During a High-Altitude Trek
}

\section{Lindsey E. Miller, Graham R. McGinnis, Brian Kliszczewicz, Dustin Slivka, Walter Hailes, John Cuddy, Charles Dumke, Brent Ruby, and John C. Quindry}

\begin{abstract}
Oxidative stress occurs as a result of altitude-induced hypobaric hypoxia and physical exercise. The effect of exercise on oxidative stress under hypobaric hypoxia is not well understood. Purpose: To determine the effect of high-altitude exercise on blood oxidative stress. Nine male participants completed a 2-d trek up and down Mt Rainer, in North America, at a peak altitude of 4,393 m. Day 1 consisted of steady-pace climbing for $6.25 \mathrm{hr}$ to a final elevation of $3,000 \mathrm{~m}$. The 4,393-m summit was reached on Day 2 in approximately $5 \mathrm{hr}$. Climb-rest intervals varied but were consistent between participants, with approximately $14 \mathrm{hr}$ of total time including rest periods. Blood samples were assayed for biomarkers of oxidative stress and antioxidant potential at the following time points: Pre (before the trek), 3Kup (at ascent to 3,000 m), 3Kdown (at 3,000 $\mathrm{m}$ on the descent), and Post (posttrek at base elevation). Blood serum variables included ferric-reducing antioxidant potential (FRAP), Trolox equivalent antioxidant capacity (TEAC), protein carbonyls (PC), and lipid hydroperoxides. Serum FRAP was elevated at 3Kup and 3Kdown compared with Pre and Post values $(p=.004,8 \%$ and $11 \%$ increase from Pre). Serum TEAC values were increased at 3Kdown and Post $(p=.032,10 \%$ and $18 \%$ increase from Pre). Serum PC were elevated at 3 Kup and 3Kdown time points ( $p=.034,194 \%$ and $138 \%$ increase from Pre), while lipid hydroperoxides were elevated Post only ( $p=.004,257 \%$ increase from Pre). Conclusions: Findings indicate that high-altitude trekking is associated with increased blood oxidative stress.
\end{abstract}

Keywords: exercise, hypoxia, reactive oxygen species

Increased production of reactive oxygen species (ROS) is a well-established response to acute exercise (Powers, Nelson, \& Hudson, 2011). ROS influence important biological functions including metabolic control, cell signaling, tissue repair, and adaptation responses to exercise stress (Powers et al., 2011). Despite these benefits, overaccumulation of ROS results in muscle-tissue damage and exacerbates inflammation (Alessio, Goldfarb, \& Cutler, 1988; Dillard, Litov, Savin, Dumelin, \& Tappel, 1978). Detrimental effects on health and normal body functioning due to ROS are collectively described as oxidative stress (Powers et al., 2011). Exercise-induced oxidative stress generally occurs as a function of increasing exercise intensity and duration (Alessio et al., 1988) in response to both aerobic- and anaerobic-type exercise (Alessio et al., 2000; Bloomer, Fry, Falvo, \& Moore,

Miller, McGinnis, Kliszczewicz, and Quindry are with the Dept. of Kinesiology, Auburn University, Auburn, AL. Slivka is with the School of Health Physical Education and Recreation, University of Nebraska at Omaha, Omaha, NE. Hailes, Cuddy, Dumke, and Ruby are with the Montana Center for Work Physiology and Exercise Metabolism, University of Montana, Missoula, MT.
2007; Bloomer, Goldfarb, Wideman, McKenzie, \& Consitt, 2005; Quindry, Stone, King, \& Broeder, 2003). However, some investigations examining lower intensity long-duration fatiguing exercise protocols have failed to find a significant increase in oxidative markers (Quindry et al., 2008; Quindry et al., 2003). Despite many advances in understanding exercise-induced oxidative stress, many unknowns remain. This noteworthy fact is particularly true about human-based applied physiology research. One such area pertains to exercise-induced oxidative stress experienced during exercise at high elevations where absolute work output is limited by oxygen availability (Wagner, 2000).

In regard to exercise at extreme altitudes, it has been proposed that hypoxia decreases antioxidant capacity, therefore resulting in greater oxidative stress and muscle fatigue (Moller, Loft, Lundby, \& Olsen, 2001; Vasankari, Kujala, Rusko, Sarna, \& Ahotupa, 1997). These findings are especially relevant to numerous individuals who travel to high altitudes for work and recreation. Comparisons between the responses to exercise at sea level versus altitude are not easily made due to alterations in relative exercise intensity versus absolute exercise work. Factors other than low oxygen availability during altitude exposure may affect the occurrence of oxidative stress and muscle fatigue. For instance, physiological stress 
from cold exposure, ultraviolet rays, and acute mountain sickness may affect the altitude-induced oxidative-stress response and warrant further investigation (Askew, 2002).

Based on this rationale, the purpose of this investigation was to examine exercise-induced oxidative stress in response to high-altitude aerobic exercise in human participants undertaking a 2-day mountaineering trek on Mt. Rainier, located in North America, at a peak altitude of 4,393 m. Oxidative stress experienced during exercise performed for health and fitness stimulates beneficial adaptations, while excessive oxidative-stress levels experienced during extreme exercise may be harmful. Therefore, this study examined blood oxidative stress in a scenario of high-altitude exercise. An oxidative-stress biomarker panel was examined in the current study to quantify exercise-induced redox changes in the blood serum. The panel included two markers of serum antioxidant potential, as well as lipid- and protein-based markers of oxidative damage (Buettner, 1993; Cao \& Prior, 1998).

\section{Methods}

\section{Subjects and Study Design}

Study approval was granted by the University of Montana's internal review board before initiation of the study, and written informed consent was obtained before data collection. Nine nonsmoking men ages $18-55$ years who were attempting a 2-day trek to the summit of Mt. Rainier $(4,393 \mathrm{~m})$ and back to base elevation $(\sim 1,000 \mathrm{~m})$ were recruited. All participants trekked with the assistance of professional mountain guides. Participants reported to the University of Montana Human Performance Mobile Laboratory located 6 miles from the Mt. Rainier park entrance in Ashford, WA. At this time, they were briefed on the purpose and methods of the study and completed a Physical Activity Readiness Questionnaire. Body weight was recorded the evening before the climb was begun and on return from the mountain using an electronic scale (Befour, Inc., Cedarburg, WI) as an indicator of poor hydration and other potentially harmful complications that might have occurred. The ascent schedule was identical for all participants. Participants took a 1-hr shuttle ride from base camp $(1,000 \mathrm{~m})$ to the 1,600 -m start site. Day 1 consisted of five climbing intervals divided into 60 min of steady-pace climbing and 15 min rest, concluding at a final elevation of 3,000 m $(10,000 \mathrm{ft})$ for a total climbing time of $6 \mathrm{hr}$ and $15 \mathrm{~min}$. The summit at 4,393 $\mathrm{m}(14,410 \mathrm{ft})$ was reached on the second day. The time to summit was $5 \mathrm{hr}$, while the return trek (to 1,600 m) was approximately $9 \mathrm{hr}$. Climb and rest intervals varied on Day 2 but were consistent between participants, with a total climb time of $14 \mathrm{hr}$. At the conclusion of the climb, the participants took a 1-hr shuttle ride back to base camp (from approximately 1,600 $\mathrm{m}$ to $1,000 \mathrm{~m}$ ). Details of the trek ascent and descent schedule are presented in Table 1 and Figure 1.

\section{Blood Serum Collection}

Blood samples were collected and assayed for blood serum biomarkers of oxidative stress and antioxidant potential at the following time points: Pre (the evening before the trek), 3Kup (at ascent to 3,000 m), 3Kdown (at 3,000 $\mathrm{m}$ on the descent), and Post (posttrek at base elevation of 1,000 $\mathrm{m}$, after the $1-\mathrm{hr}$ shuttle ride). Five milliliters of venous blood were collected from an antecubital vein and allowed to clot on ice for $20 \mathrm{~min}$. Blood was then immediately centrifuged at $3,400 \mathrm{rpm}$ for 20 min in a portable centrifuge (centri A13, Jouan Inc., Winchester, VA). Serum was separated and immediately frozen on dry ice. Serum was kept temporarily on dry ice for 5 days and stored at $-80^{\circ} \mathrm{C}$ until assay. All blood samples were collected under nonfasted conditions. Diet was not controlled between subjects throughout the trek for logistical reasons, but all subjects were encouraged to eat and drink during the rest intervals.

Table 1 Trek Climb and Rest Schedule

\begin{tabular}{|c|c|c|c|c|c|c|c|}
\hline Day & Stage & $\begin{array}{l}\text { Approximate blood- } \\
\text { sampling time }\end{array}$ & $\begin{array}{l}\text { Trek } \\
\text { duration }\end{array}$ & $\begin{array}{l}\text { Rest } \\
\text { duration }\end{array}$ & $\begin{array}{l}\text { Total trek time } \\
\text { per stage }\end{array}$ & $\begin{array}{l}\text { Altitude } \\
\text { achieved }\end{array}$ & $\begin{array}{l}\text { Total trek time } \\
\text { per day }\end{array}$ \\
\hline 0 & Pre & 7 p.m. & & & & & \\
\hline \multirow[t]{5}{*}{1} & 1 & & $60 \mathrm{~min}$ & $15 \mathrm{~min}$ & $1.25 \mathrm{hr}$ & $3,000 \mathrm{~m}$ & $6.25 \mathrm{hr}$ \\
\hline & 2 & & $60 \mathrm{~min}$ & $15 \mathrm{~min}$ & $1.25 \mathrm{hr}$ & & \\
\hline & 3 & & $60 \mathrm{~min}$ & $15 \mathrm{~min}$ & $1.25 \mathrm{hr}$ & & \\
\hline & 4 & & $60 \mathrm{~min}$ & $15 \mathrm{~min}$ & $1.25 \mathrm{hr}$ & & \\
\hline & 5 & 3 p.m. & $60 \mathrm{~min}$ & $15 \mathrm{~min}$ & $1.25 \mathrm{hr}$ & & \\
\hline \multirow[t]{3}{*}{2} & 1 & & varying & varying & $5 \mathrm{hr}$ & $4,393 \mathrm{~m}$ & $14 \mathrm{hr}$ \\
\hline & 2 & 11 a.m. & varying & varying & $4 \mathrm{hr}$ & $3,000 \mathrm{~m}$ & \\
\hline & 3 & 4:30 a.m. & varying & varying & $5 \mathrm{hr}$ & $1,000 \mathrm{~m}$ & \\
\hline
\end{tabular}




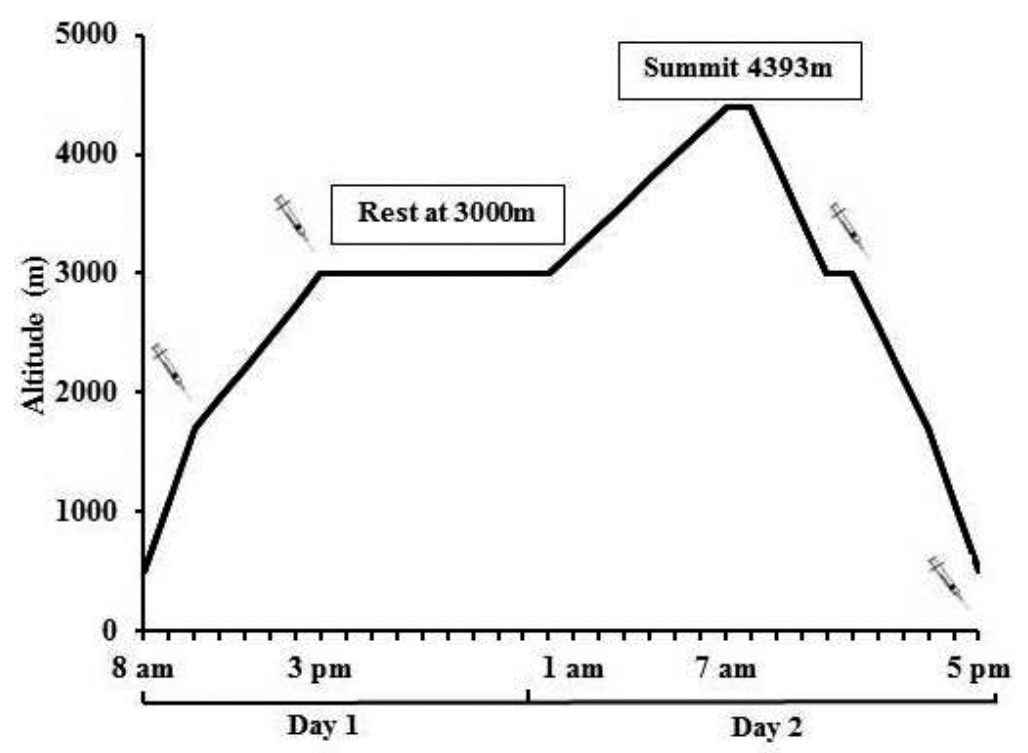

Figure 1 - Trek timeline. Syringe icons indicate blood-collection time points.

\section{Biochemical Assays for Serum Antioxidant Capacity and Potential}

Serum nonenzymatic antioxidant capacity (NEAC) was measured by the serum Trolox equivalent antioxidant capacity (TEAC) assay modified from the methods of Re et al. (1999) and Villano, Fernandez-Pachon, Troncoso, and Garcia-Parrilla (2004). The TEAC assay is based on the principle that oxidized 2,2'-azinobis-(3-ethylbenzothiazoline-6-sulfonic acid) is reduced by antioxidants present in the blood serum (Re et al., 1999; Villano et al., 2004). Serum antioxidant potential was quantified via the ferric-reducing antioxidant potential (FRAP) assay according to methodology modified from Benzie and Strain (1996). The assay principle is based on the ion reduction of ferric compounds to ferrous, forming tripyridyltriazine complex with the use of 0- to 1,000$\mu \mathrm{M}$ ascorbic acid standards (Benzie \& Strain, 1996). Antioxidant capacity is a direct method of quantifying the NEAC of serum utilizing the ability of serum to inhibit oxidation of an indicator substance, while antioxidant potential is an indirect method in which the total reductive properties of serum are quantified by the addition of a known oxidant (Bartosz, 2010). Both TEAC and FRAP result in the formation of colorimetric solutions that can be assessed spectrophotometrically (Benzie \& Strain, 1996; Re et al., 1999; Villano et al., 2004).

\section{Biochemical Assays for Serum Biomarkers of Oxidative Damage}

Serum protein carbonyls and lipid hydroperoxides were used to quantify oxidative damage in samples collected during the trek. Serum protein carbonyl concentration was quantified as a marker of protein oxidation. Total protein content was first determined based on the methods of Bradford (1976) to normalize total protein content in individual samples before the protein carbonyl assay. Serum samples were assayed using a commercially available ELISA kit for protein carbonyl content (Biocell, Papatoetoe New Zealand) according to assay instructions and reported as $\mu \mathrm{M} / \mathrm{mg}$ protein. Lipid peroxidation was measured via ferrous oxidation-xylenol orange assay modified from Nourooz-Zadeh et al. (1994) and reported as $\mu \mathrm{mol} / \mathrm{L}$ serum. The assay principle is based on the oxidation of ferrous ions to ferric ions by lipid hydroperoxides and the formation of a colored complex that was quantified spectrophotometrically (Nourooz-Zadeh, Tajaddini-Sarmadi, \& Wolff, 1994).

\section{Statistical Analysis}

A one-way repeated-measures ANOVA was used to assess differences between time points with paired $t$ tests to determine between-samples time differences when appropriate. For key dependent variables, a Mauchly's test confirmed that there were no violations in sphericity. Statistical tests were performed using SPSS version 19.0 (Chicago, IL). Significance was set a priori at $p \leq$ .05 for ANOVA.

\section{Results}

\section{Subject Characteristics}

All participants completed the trek within a 30-min time window of each other. Participant body weights were not significantly different between Pre $(76.0 \pm 4.0 \mathrm{~kg})$ and Post $(74.8 \pm 3.9 \mathrm{~kg})$ measurements $(p=.830)$. 


\section{Biochemical Assays}

Serum Antioxidant Capacity and Potential.

In response to the Mt. Rainier excursion, mean responses for both TEAC, main effect of time $F(3,30)=3.42, p=$ .034 , and FRAP, main effect of time $F(3,15)=217.1$, $p=.004$, were observed to increase compared with baseline Pre values. Group means for TEAC and FRAP are presented in Figure 2. Serum TEAC elevations were observed in 3Kdown $(+10 \%$, paired-samples $t$ test Pre vs. 3Kdown; $p=.023)$ and Post $(+18 \%$, paired-samples $t$ test Pre vs. Post; $p=.028$ ) serum samples compared with Pre baseline values. Post values were also significantly elevated from 3Kup values (paired $t$ test Post vs. 3Kup; $p$ $=.028$ ). For serum FRAP samples, significant increases in antioxidant potential were observed at $3 \mathrm{Kup}(+8 \%$, paired $t$ test Pre vs. 3Kup; $p=.02)$ and 3 Kdown $(+11 \%$, paired $t$ test Pre vs. 3Kdown; $p=.001)$ time points compared with the Pre baseline time point.

\section{Serum Biomarkers of Oxidative Damage.}

Serum protein carbonyls, main effect of time $F(3,27)=$ $3.340, p=.034$, and lipid hydroperoxides, main effect of time $F(3,15)=25.415, p=.004$, were elevated by the high-altitude trekking. Mean serum protein carbonyl and lipid hydroperoxide concentrations are presented for each time point in Figure 3. Compared with Pre, serum protein

(a)

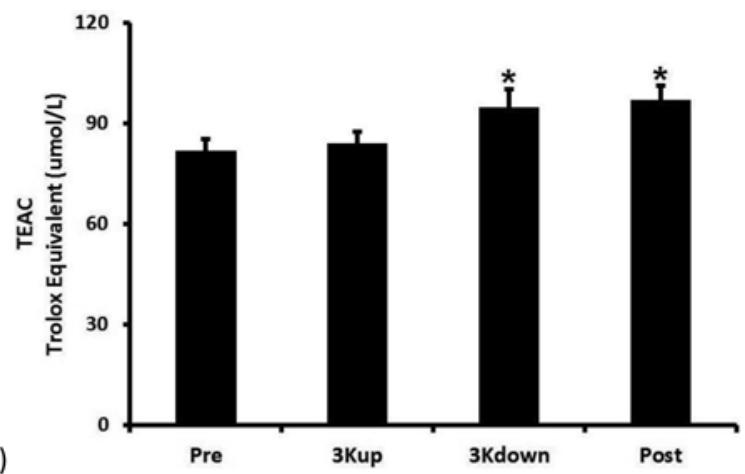

(b)

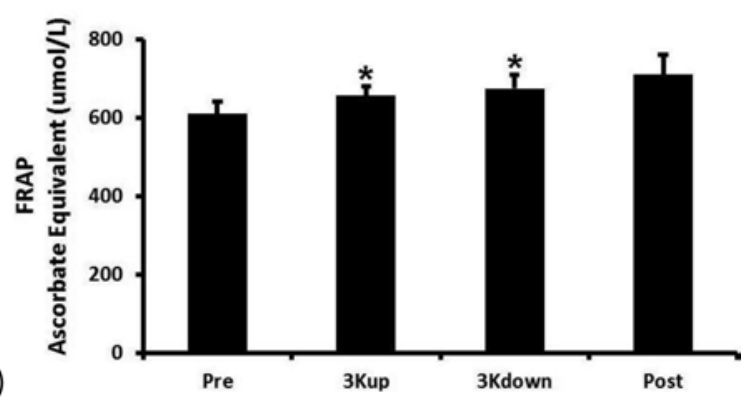

Figure 2 - Biomarkers of serum antioxidant capacity during a trek up Mt. Rainier. (a) Trolox equivalent antioxidant capacity (TEAC). (b) Ferric-reducing antioxidant potential (FRAP). Pre $=$ before the trek; $3 \mathrm{Kup}=$ at ascent to 3,000 m; 3Kdown $=$ at $3,000 \mathrm{~m}$ on the descent; Post $=$ posttrek at base elevation. Values represent group means at specific time points, presented as $M \pm S E M, n=9$ per time point. *Significantly elevated from Pre; $p \leq .05$. carbonyls were elevated in 3Kup $(+194 \%$, paired-samples $t$ test Pre vs. 3Kup; $p=.046)$ and 3Kdown $(+138 \%$, paired-samples $t$ test Pre vs. 3Kdown; $p=.049)$ time samples. There were also significant differences between 3 Kup and Post values (paired-samples $t$ test 3Kup vs. Post; $p=.034$ ). For serum lipid hydroperoxides, there was a significant difference between sample times in that lipid hydroperoxides were elevated significantly at Post sampling compared with Pre values $(257 \%$, pairedsamples $t$ test Pre vs. Post; $p=.026$ ).

\section{Discussion}

The purpose of this investigation was to quantify alterations in the blood serum biomarkers of oxidative stress and NEAC in response to high-altitude mountain trekking in a field-based research setting. Blood samples were collected over 2 days during a trek up Mt. Rainier, which summits at an elevation of 4,393 $\mathrm{m}$. The major findings of this study indicate that redox perturbations occur during exercise at high altitude. This conclusion is based on the observation of increased serum NEAC and alterations in serum oxidative-damage markers. This study is a

(a)
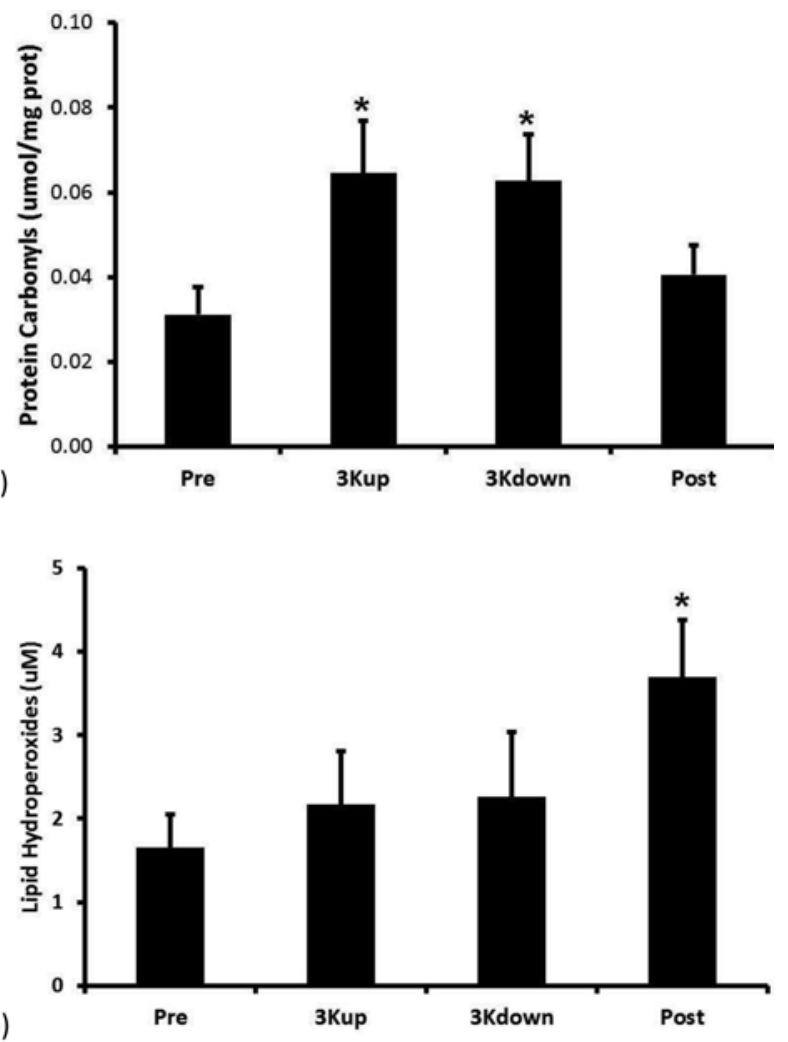

Figure 3 - Biomarkers of serum oxidative damage during a trek up Mt. Rainier. (a) Serum protein carbonyls. (b) Serum lipid hydroperoxides. Pre = before the trek; $3 \mathrm{Kup}=$ at ascent to $3,000 \mathrm{~m} ; 3$ Kdown $=$ at $3,000 \mathrm{~m}$ on the descent Post $=$ posttrek at base elevation. Values represent group means at specific time points, presented as $M \pm S E M, n=9$ per time point. *Significantly elevated from Pre; $p \leq .05$. 
novel, comprehensive examination of the oxidative-stress response to exercise at high altitude in an applied field condition. The observed oxidative stress in recreational trekkers who did not experience untoward events due to altitude may have implications for those who work or recreate at high altitude.

In the current study, the cellular mechanisms responsible for the observed oxidative stress are currently unclear. The mechanisms of oxidant production may vary between normoxic and hypoxic exercise (Moller et al., 2001). Based on existing literature, contributing ROS sources during the trek on Mt. Rainier may include mitochondria, auto-oxidation of catecholamines, and various oxidases (i.e., xanthine oxidase, NADPH oxidase). Production of superoxide resulting from increased mitochondrial oxygen uptake at Complexes I and III (Boveris \& Chance, 1973) during exercise is historically accepted as a predominant source of ROS (Packer, 1997; Pattwell \& Jackson, 2004). However, exercise intensity at higher elevations is disproportionate to sea-level exercise for a given absolute workload (i.e., higher intensity at high altitude). Based on current understanding, exercise-induced fatigue at these elevations likely results in oxidative stress via the activation of xanthine oxidase, auto-oxidation of catecholamines, or infiltrating leukocytes (Hellsten, Frandsen, Orthenblad, Sjodin, \& Richter, 1997; Jackson, 1994; Packer, 1997; Singh, 1992).

The potential role of xanthine-oxidase-generated ROS is compelling in the current study. Xanthine oxidase converts xanthine formed from ADP to uric acid and superoxide (Jackson, 1994; Kanter, 1998). As such, serum uric acid content is held to be indicative of this oxidative load associated with purine metabolism during exercise. Given that uric acid represents the primary antioxidant contribution to plasma FRAP values (Cao \& Prior, 1998; Hudson et al., 2008), our results likely reflect an increase in uric acid production during the trek. In support, we have previously demonstrated significant correlations between postexercise FRAP and uric acid levels in blood plasma (Hudson et al., 2008). Our FRAP results in combination with serum elevations in TEAC indicate that serum NEAC was increased during the trek up Mt. Rainier. Discrepancies between the time-course response for TEAC and FRAP values may be due to the rate of oxidation of various endogenous antioxidants reflected in these two assays. In support, the TEAC assay is largely sensitive to plasma albumin and other aqueous-phase antioxidants and includes sulfhydryl groups (Cao \& Prior, 1998). Our findings are consistent with the biological pecking order of antioxidant systems (Buettner, 1993) and previous research indicating an immediate response of increased uric acid while aqueous antioxidants return to baseline soon during recovery (Quindry et al., 2003). The overall increase in antioxidant capacity and antioxidant potential supports previous research indicating the ability of antioxidant defense systems to tightly regulate the level of oxidative stress (Hudson et al., 2008; Quindry et al., 2011; Quindry et al., 2008).

Protein carbonyls and lipid hydroperoxides were measured as biomarkers of oxidative stress. High- altitude trekking resulted in significant elevations for both oxidative-damage biomarkers and confirms that an oxidative-stress response occurred during the exercise challenge. The appearance of protein carbonyls is observed to occur early in response to exercise (Hudson et al., 2008) and is the direct result of protein oxidation, lipid peroxidation, and the reaction of reducing sugars (Dalle-Donne, Rossi, Giustarini, Milzani, \& Colombo, 2003). Protein carbonyls are stable in human plasma for at least $4 \mathrm{hr}$ before selective degradation, largely by proteasomes (Grune, Reinheckel, \& Davies, 1996; Pantke et al., 1999). The values observed in the current study are relatively low, although they are in accordance with previously published results from our laboratory and others (Bloomer et al., 2006; Bloomer et al., 2007). We observed a trek-induced rise in protein carbonyls at 3Kup and 3Kdown. Protein carbonyl concentrations in Post serum samples, collected at lower elevations, were statistically similar to Pre values. Approximately $4 \mathrm{hr}$ elapsed from the $3 \mathrm{Kdown}$ sampling time point and 1-hr bus ride to base camp where Post sampling occurred. This finding is in accordance with previous research indicating that protein carbonyl formation occurs relatively early in the oxidation cascade (Bloomer et al., 2007) and is degraded within hours or days (Pantke et al., 1999). Direct comparisons of blood oxidative markers between the current and previous studies are difficult due to the large differences between exercise duration and intensities. For example, Bloomer et al. (2006) found $111 \%$ and $74 \%$ increases in protein carbonyl concentration after intense sprint and squat exercises at normoxia. In the current study, we observed a $194 \%$ and $138 \%$ increase at $3 \mathrm{Kup}$ and $3 \mathrm{Kdown}$, respectively. Conversely, two studies demonstrated no change in protein carbonyls after ultramarathon exercise more closely matched to the current study design (Nieman et al., 2003; Quindry et al., 2008). Although direct comparisons between studies are not possible, we speculate that prolonged endurance exercise and hypobaric hypoxia may have an additive effect on serum markers of oxidative stress.

Our second biomarker of oxidative damage, lipid hydroperoxides, increased by $257 \%$ at the Post sampling time point compared with Pre baseline values. This observed rise in serum lipid hydroperoxides is notably different from what was observed for protein carbonyls, and is likely due to the rate of appearance and degradation for these labile redox compounds (Frei, Stocker, \& Ames, 1988). While protein carbonyls are relatively stable in the hours after exercise, lipid hydroperoxides can be degraded within minutes of their formation (Dalle-Donne et al., 2003). Other reports demonstrate an initial increase in lipid hydroperoxide concentration without change in the protein carbonyl levels after intense exercise (5-min stages of treadmill running at 40\%, 70\%, and $100 \% \mathrm{VO}_{2 \max }$ with 15 min rest between stages; Fogarty et al., 2011). Our data do not reflect this finding, however, because our high-altitude trek exercise (14 total hr of continuous low-intensity concentric-eccentric exercise over 2 days) is vastly different from the previously referenced study design (Fogarty et al., 2011). It 
is possible that muscle damage occurred due to eccentric muscle activity during the trek descent, causing inflammation, phagocytic white-cell recruitment (Hellsten et al., 1997), and increased formation of lipid hydroperoxides (Child et al., 1999; Nikolaidis et al., 2008). Although the 3Kdown sample was taken after an initial descent portion of the trek, our findings would corroborate those of many studies that have shown that alterations in lipid hydroperoxides appear in the hours after a damaging eccentric-exercise stimulus (Nikolaidis et al., 2008). Damaging muscle exercise may also result in increased circulating levels of polyunsaturated fatty acids due to rupture of the skeletal-muscle-cell membrane (Nikolaidis \& Mougios, 2004). Polyunsaturated fatty acids are more susceptible to oxidation than are saturated fatty acids and may account for the observed increase in lipid hydroperoxide concentrations after damaging eccentric exercise at the Post sampling time point (Hulbert, 2005). However, some evidence indicates that oxidative stress occurs mostly as a result of concentric muscle exercise (Pattwell \& Jackson, 2004), which is consistent with the extended duration of the ascent portion of the trek and our protein carbonyl data. Moreover, we recently examined lipid hydroperoxide levels in the days after a single bout of muscle-damaging eccentric quadriceps exercise and found no elevation in postexercise blood plasma samples (Quindry et al., 2011). The differences between these previous findings likely reflect the vast difference in total work performed (i.e., single-bout eccentric exercise vs. $9 \mathrm{hr}$ of downhill trekking with a significant eccentric component). The current study demonstrated a $257 \%$ increase in lipid hydroperoxide concentration. A previous investigation reported a more modest $88 \%$ increase in lipid hydroperoxides after an ultramarathon race (Nieman et al., 2003). Further investigation may clarify the lipid hydroperoxide response to varying exercise durations and intensities at high altitude. Collectively, the observed rise in protein carbonyl and lipid hydroperoxide formation indicates that a significant level of oxidative damage occurred in response to high-altitude mountain trekking by our participants.

\section{Study Limitations}

Limitations of the current study include the fact that participants were recruited on site, and, as such, their individual skill and fitness level was not assessed before inclusion in the study. Nonetheless, all participants completed the trek with the guidance of experienced mountaineers according to a prescribed time schedule. Due to the nature of the subject recruitment, we were unable to control individual dietary differences, which may have influenced oxidative-stress outcomes. In defense of the current study design, we previously demonstrated that high-dose dietary antioxidant supplement use did not influence blood oxidative-stress variables during ultramarathon exercise (Quindry et al., 2008). Factors other than low oxygen availability during altitude exposure may also affect the formation of oxidative stress and muscle fatigue, including physiological stress from cold exposure, ultraviolet radiation, and dehydration (Askew, 2002). The extent to which each of these factors contributed to the observed results is unknown. However, including these factors in an applied field setting adds novelty to the current study design, as they would likely be unaccounted for in a laboratory setting. We were unable to determine the presence of muscle damage or oxygen consumption during the trek, which may have influenced oxidative-stress measures. Specific serum antioxidants were not measured due to the labile nature of water-soluble antioxidants in blood serum and the inevitable time lapse between sample collection and biochemical analysis.

\section{Conclusions}

Individuals who work and recreate at high altitude may experience potentially deleterious oxidative stress due to altitude exposure, extreme muscle exercise, and complications such as acute mountain sickness (Askew, 2002). Paradoxically, oxidative stress stimulates muscle adaptations to exercise and hypoxia (Gomez-Cabrera, Domenech, \& Vina, 2008; Powers et al., 2011; Ristow et al., 2009). Therefore, it is important to identify redox perturbations that occur during exercise at high altitude. Our findings, in recreational hikers who did not report untoward events, indicate a significant increase in serum oxidative-damage markers and increased serum antioxidant capacity/potential in response to high-altitude mountain trekking. Further research is needed to determine the oxidative-stress response to more intense exercise and complications experienced at high altitude.

\section{Acknowledgments}

The funding for this study was provided by internal funding from the University of Montana. There was no conflict of interest with respect to this study.

\section{References}

Alessio, H.M., Goldfarb, A.H., \& Cutler, R.G. (1988). MDA content increases in fast- and slow-twitch skeletal muscle with intensity of exercise in a rat. The American Journal of Physiology, 255(6 Pt 1), C874-C877. PubMed

Alessio, H.M., Hagerman, A.E., Fulkerson, B.K., Ambrose, J., Rice, R.E., \& Wiley, R.L. (2000). Generation of reactive oxygen species after exhaustive aerobic and isometric exercise. Medicine and Science in Sports and Exercise, 32(9), 1576-1581. PubMed doi:10.1097/00005768200009000-00008

Askew, E.W. (2002). Work at high altitude and oxidative stress: Antioxidant nutrients. Toxicology, 180(2), 107-119. PubMed doi:10.1016/S0300-483X(02)00385-2

Bartosz, G. (2010). Non-enzymatic antioxidant capacity assays: Limitations of use in biomedicine. Free Radical Research, 44(7), 711-720. PubMed doi:10.3109/10715761003758114 
Benzie, I.F., \& Strain, J.J. (1996). The ferric reducing ability of plasma (FRAP) as a measure of "antioxidant power": The FRAP assay. Analytical Biochemistry, 239(1), 70-76. PubMed doi:10.1006/abio.1996.0292

Bloomer, R.J., Falvo, M.J., Fry, A.C., Schilling, B.K., Smith, W.A., \& Moore, C.A. (2006). Oxidative stress response in trained men following repeated squats or sprints. Medicine and Science in Sports and Exercise, 38(8), 1436-1442. PubMed doi:10.1249/01.mss.0000227408.91474.77

Bloomer, R.J., Fry, A.C., Falvo, M.J., \& Moore, C.A. (2007). Protein carbonyls are acutely elevated following single set anaerobic exercise in resistance trained men. Journal of Science and Medicine in Sport, 10(6), 411-417. PubMed doi:10.1016/j.jsams.2006.07.014

Bloomer, R.J., Goldfarb, A.H., Wideman, L., McKenzie, M.J., $\&$ Consitt, L.A. (2005). Effects of acute aerobic and anaerobic exercise on blood markers of oxidative stress. Journal of Strength and Conditioning Research, 19(2), 276-285. PubMed

Boveris, A., \& Chance, B. (1973). The mitochondrial generation of hydrogen peroxide. General properties and effect of hyperbaric oxygen. Biochemical Journal, 134(3), 707-716. PubMed

Bradford, M.M. (1976). A rapid and sensitive method for the quantitation of microgram quantities of protein utilizing the principle of protein-dye binding. Analytical Biochemistry, 72, 248-254. PubMed doi:10.1016/00032697(76)90527-3

Buettner, G.R. (1993). The pecking order of free radicals and antioxidants: Lipid peroxidation, alpha-tocopherol, and ascorbate. Archives of Biochemistry and Biophysics, 300(2), 535-543. PubMed doi:10.1006/abbi.1993.1074

Cao, G., \& Prior, R.L. (1998). Comparison of different analytical methods for assessing total antioxidant capacity of human serum. Clinical Chemistry, 44(6 Pt 1), 1309-1315. PubMed

Child, R., Brown, S., Day, S., Donnelly, A., Roper, H., \& Saxton, J. (1999). Changes in indices of antioxidant status, lipid peroxidation and inflammation in human skeletal muscle after eccentric muscle actions. Clinical Science (London, England), 96(1), 105-115. PubMed doi:10.1042/ CS19980146

Dalle-Donne, I., Rossi, R., Giustarini, D., Milzani, A., \& Colombo, R. (2003). Protein carbonyl groups as biomarkers of oxidative stress. Clinica Chimica Acta, 329(1-2), 23-38. PubMed doi:10.1016/S0009-8981(03)00003-2

Dillard, C.J., Litov, R.E., Savin, W.M., Dumelin, E.E., \& Tappel, A.L. (1978). Effects of exercise, vitamin E, and ozone on pulmonary function and lipid peroxidation. Journal of Applied Physiology: Respiratory, Environmental and Exercise Physiology, 45(6), 927-932. PubMed

Fogarty, M.C., Hughes, C.M., Burke, G., Brown, J.C., Trinick, T.R., Duly, E., ... Davison, G.W. (2011). Exercise-induced lipid peroxidation: Implications for deoxyribonucleic acid damage and systemic free radical generation. Environmental and Molecular Mutagenesis, 52(1), 35-42. PubMed doi:10.1002/em.20572

Frei, B., Stocker, R., \& Ames, B.N. (1988). Antioxidant defenses and lipid peroxidation in human blood plasma. Proceedings of the National Academy of Sciences of the
United States of America, 85(24), 9748-9752. PubMed doi:10.1073/pnas.85.24.9748

Gomez-Cabrera, M.C., Domenech, E., \& Vina, J. (2008). Moderate exercise is an antioxidant: Upregulation of antioxidant genes by training. Free Radical Biology \& Medicine, 44(2), 126-131. PubMed doi:10.1016/j.freeradbiomed.2007.02.001

Grune, T., Reinheckel, T., \& Davies, K.J. (1996). Degradation of oxidized proteins in K562 human hematopoietic cells by proteasome. The Journal of Biological Chemistry, 271(26), 15504-15509. PubMed doi:10.1074/jbc.271.26.15504

Hellsten, Y., Frandsen, U., Orthenblad, N., Sjodin, B., \& Richter, E.A. (1997). Xanthine oxidase in human skeletal muscle following eccentric exercise: A role in inflammation. The Journal of Physiology, 498(Pt 1), 239-248. PubMed

Hudson, M.B., Hosick, P.A., McCaulley, G.O., Schrieber, L., Wrieden, J., McAnulty, S.R., . . Quindry, J.C. (2008). The effect of resistance exercise on humeral markers of oxidative stress. Medicine and Science in Sports and Exercise, 40(3), 542-548. PubMed doi:10.1249/ MSS.0b013e31815daf89

Hulbert, A.J. (2005). On the importance of fatty acid composition of membranes for aging. Journal of Theoretical Biology, 234(2), 277-288. PubMed doi:10.1016/j. jtbi.2004.11.024

Jackson, M.J. (1994). Exercise and oxygen radical production by muscle. In C. Sen, L. Packer, \& O. Hanninen (Eds.). Exercise and oxygen toxicity (pp. 57-68). Amsterdam, New York: Elsevier.

Kanter, M. (1998). Free radicals, exercise and antioxidant supplementation. The Proceedings of the Nutrition Society, 57(1), 9-13. PubMed doi:10.1079/PNS19980004

Moller, P., Loft, S., Lundby, C., \& Olsen, N.V. (2001). Acute hypoxia and hypoxic exercise induce DNA strand breaks and oxidative DNA damage in humans. FASEB Journal, 15(7), 1181-1186. PubMed doi:10.1096/fj.00-0703com

Nieman, D.C., Dumke, C.I., Henson, D.A., McAnulty, S.R., McAnulty, L.S., Lind, R.H., \& Morrow, J.D. (2003). Immune and oxidative changes during and following the Western States Endurance Run. International Journal of Sports Medicine, 24(7), 541-547. PubMed doi:10.1055/s-2003-42018

Nikolaidis, M.G., Jamurtas, A.Z., Paschalis, V., Fatouros, I.G., Koutedakis, Y., \& Kouretas, D. (2008). The effect of muscle-damaging exercise on blood and skeletal muscle oxidative stress: Magnitude and time-course considerations. Sports Medicine (Auckland, N.Z.), 38(7), 579-606. PubMed doi:10.2165/00007256-200838070-00005

Nikolaidis, M.G., \& Mougios, V. (2004). Effects of exercise on the fatty-acid composition of blood and tissue lipids. Sports Medicine (Auckland, N.Z.), 34(15), 1051-1076. PubMed doi:10.2165/00007256-200434150-00004

Nourooz-Zadeh, J., Tajaddini-Sarmadi, J., \& Wolff, S.P. (1994). Measurement of plasma hydroperoxide concentrations by the ferrous oxidation-xylenol orange assay in conjunction with triphenylphosphine. Analytical Biochemistry, 220(2), 403-409. PubMed doi:10.1006/abio.1994.1357

Packer, L. (1997). Oxidants, antioxidant nutrients and the athlete. Journal of Sports Sciences, 15(3), 353-363. PubMed doi:10.1080/026404197367362 
Pantke, U., Volk, T., Schmutzler, M., Kox, W.J., Sitte, N., \& Grune, T. (1999). Oxidized proteins as a marker of oxidative stress during coronary heart surgery. Free Radical Biology \& Medicine, 27(9-10), 1080-1086. PubMed doi:10.1016/S0891-5849(99)00144-6

Pattwell, D.M., \& Jackson, M.J. (2004). Contraction-induced oxidants as mediators of adaptation and damage in skeletal muscle. Exercise and Sport Sciences Reviews, 32(1), 14-18. PubMed doi:10.1097/00003677-200401000-00004

Powers, S.K., Nelson, W.B., \& Hudson, M.B. (2011). Exerciseinduced oxidative stress in humans: Cause and consequences. Free Radical Biology \& Medicine, 51(5),942950. PubMed doi:10.1016/j.freeradbiomed.2010.12.009

Quindry, J., Miller, L., McGinnis, G., Irwin, M., Dumke, C., Magal, M., . . . Urbiztondo, Z. (2011). Muscle-fiber type and blood oxidative stress after eccentric exercise. International Journal of Sport Nutrition and Exercise Metabolism, 21(6), 462-470. PubMed

Quindry, J.C., McAnulty, S.R., Hudson, M.B., Hosick, P., Dumke, C., McAnulty, L.S., . . Nieman, D. (2008). Oral quercetin supplementation and blood oxidative capacity in response to ultramarathon competition. International Journal of Sport Nutrition and Exercise Metabolism, 18(6), 601-616. PubMed

Quindry, J.C., Stone, W.L., King, J., \& Broeder, C.E. (2003). The effects of acute exercise on neutrophils and plasma oxidative stress. Medicine and Science in Sports and Exercise, 35(7), 1139-1145. PubMed doi:10.1249/01. MSS.0000074568.82597.0B
Re, R., Pellegrini, N., Proteggente, A., Pannala, A., Yang, M., \& Rice-Evans, C. (1999). Antioxidant activity applying an improved ABTS radical cation decolorization assay. Free Radical Biology \& Medicine, 26(9-10), 1231-1237. PubMed doi:10.1016/S0891-5849(98)00315-3

Ristow, M., Zarse, K., Oberbach, A., Kloting, N., Birringer, M., Kiehntopf, M., ... Bluher, M. (2009). Antioxidants prevent health-promoting effects of physical exercise in humans. Proceedings of the National Academy of Sciences of the United States of America, 106(21), 8665-8670. PubMed doi:10.1073/pnas.0903485106

Singh, V.N. (1992). A current perspective on nutrition and exercise. The Journal of Nutrition, 122(3, Suppl) 760-765. PubMed

Vasankari, T.J., Kujala, U.M., Rusko, H., Sarna, S., \& Ahotupa, M. (1997). The effect of endurance exercise at moderate altitude on serum lipid peroxidation and antioxidative functions in humans. European Journal of Applied Physiology and Occupational Physiology, 75(5), 396-399. PubMed doi:10.1007/s004210050178

Villano, D., Fernandez-Pachon, M.S., Troncoso, A.M., \& Garcia-Parrilla, M.C. (2004). The antioxidant activity of wines determined by the $\mathrm{ABTS}^{+}$method: Influence of sample dilution and time. Talanta, 64(2), 501-509. PubMed doi:10.1016/j.talanta.2004.03.021

Wagner, P.D. (2000). Reduced maximal cardiac output at altitude-Mechanisms and significance. Respiration Physiology, 120(1), 1-11. PubMed doi:10.1016/S00345687(99)00101-2 